\title{
当科における外傷性股関節後方脱臼の治療成績
}

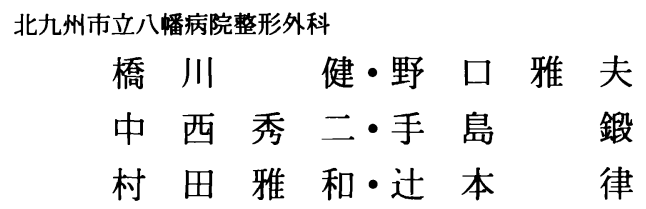

\section{Results of Treatment for Traumatic Posterior \\ Fracture-Dislocation of the Hip}

by

\author{
Takeshi Hashikawa, Masao Noguchi, Shuji Nakanishi, Kitau Teshima, \\ Masakazu Murata and Ritsu Tsujimoto \\ Department of Orthopaedic Surgery, Kitakyushu City Yahata Hospital
}

\begin{abstract}
We reviewed the clinical results of 17 cases that had been treated for traumatic posterior fracture-dislocation of the hip at our hospital. Of these cases, 14 were male and 3 were female, their ages ranging from 17 to 67 years (mean; 34.3 years). The follow-up period was 6 months to 5 years and 8 months (mean; 2 years and 6 months).

The results of 15 of these cases were classified by the Thompson and Epstein classification. 3 were "exellent", 11 were "good", and only 1 was "fair". There was no "poor" case, nor any cases with avascularnecrosis of the femoral head and osteoarthritis. The other 2 cases received prosthetic replacement of the hip due to femoral neck fracture that occured during the reduction procedure.

We recommend that dislocation of the hip be reduced as soon as possible, but carefully.
\end{abstract}

Key words : Traumatic Posterior Fracture-Dislocation of the Hip (外傷性股関節後方脱臼), Avascular Necrosis of the Femoral Head (大腿骨頭壊死), Osteoarthrosis（変形性関節 症)

はじめに

外傷性股関節脱臼は寛骨臼骨折または骨頭骨折を伴 うことが多く, 後に大腿骨頭壊死や変形性関節症が生 じ，股関節の機能障害を残すことがある．今回，我々 はこの治療成績を知る目的で自験例の調査を行った.

\section{対象及び方法}

対象は当科で治療を行い，6 6 力以上経過観察し得 た外傷性股関節後方脱臼 17 例である. 男性 14 例, 女 性 3 例で, 受傷時年齢は 17 歳から 67 歳, 平均 34.3 歳, 受傷機転は交通事故 15 例, 転倒 1 例, 転落 1 例
であった。経過観察期間は, 6 力月から 5 年 8 力月, 平均 2 年 6 力月であった.

対象を Thompson \& Epstein の股関節脱臼骨折分 類 (以下 T-分類 $)^{17)}$ で分類すると, type I；3 例, type II ; 4 例, type III ; 2 例, type IV ; 0 , type V 8 例，であった。 $\mathrm{T}$-分類 type V 8 例の骨頭骨 折型を Pipkin の骨頭骨折分類 (以下 $\mathrm{P}-$ 分類) に従っ て分類すると, type I ; 5例, type II；1例, type III；2 例であった（表 1 ).

$\mathrm{P}$-分類 type III の 2 例を除く 15 例は直ちに脱臼 整復を行った. 受傷から整復までの時間は 2 時間から 7 時間，平均 4.1 時間であった。 $\mathrm{P}$-分類 type III の 
表 1 対象症例の詳細

\begin{tabular}{|c|c|c|c|c|c|c|c|c|c|}
\hline 症例 & 性別 & 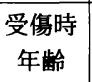 & $\mathrm{T}$-分類 & $\mathrm{P}$-分類 & $\begin{array}{c}\text { 整復までの } \\
\text { 時間 }\end{array}$ & 手術法 & $\begin{array}{c}\text { 免荷期間 } \\
\text { （週） }\end{array}$ & $\begin{array}{c}\text { 経過観察期間 } \\
\text { (月） }\end{array}$ & 臨床成績 \\
\hline 1 & 男 & 19 & I & • & 3 & 保存的治療 & 8 & 26 & good \\
\hline 2 & 男 & 21 & I & • & 3 & 保存的治療 & 8 & 24 & good \\
\hline 3 & 女 & 23 & I & - & 3 & 保存的治療 & 6 & 60 & excellent \\
\hline 4 & 男 & 18 & II & • & 3 & 骨接合 & 13 & 30 & good \\
\hline 5 & 男 & 40 & II & • & 6 & 骨接合 & 8 & 43 & good \\
\hline 6 & 男 & 67 & II & - & 3 & 骨接合 & 14 & 55 & good \\
\hline 7 & 男 & 23 & II & - & 4 & 骨接合 & 11 & 36 & good \\
\hline 8 & 男 & 59 & III & - & 7 & 骨接合・小骨片除去 & 12 & 33 & excellent \\
\hline 9 & 男 & 57 & III & • & 5 & 小骨片除去 & 8 & 6 & good \\
\hline 10 & 男 & 18 & $\mathrm{~V}$ & I & 2 & 骨接合 & 7 & 32 & good \\
\hline 11 & 男 & 45 & $\mathrm{~V}$ & I & 5 & 保存的治療 & 12 & 6 & excellent \\
\hline 12 & 男 & 30 & $\mathrm{~V}$ & I & 6 & 保存的治療 & 8 & 12 & good \\
\hline 13 & 男 & 17 & $\mathrm{~V}$ & I & 3 & 保存的治療 & 13 & 30 & good \\
\hline 14 & 女 & 29 & $\mathrm{~V}$ & I & 5 & 骨接合 & 13 & 29 & fair \\
\hline 15 & 男 & 31 & $\mathrm{~V}$ & II & 4 & 骨接合 & 14 & 28 & good \\
\hline 16 & 女 & 45 & $\mathrm{~V}$ & III & 整復できず & 人工骨頭置換 & - & 68 & - \\
\hline 17 & 男 & 41 & $\mathrm{~V}$ & III & 整復できず & 人工骨頭置換 & • & 26 & • \\
\hline
\end{tabular}

表 2 Thompson \& Epstein の臨床成績判定基準

\begin{tabular}{c|c|c|c|c}
\hline \hline & excellent & good & fair & poor \\
\hline 股 関節 痛 & なし & なし & $\begin{array}{c}\text { ある } \\
\text { (労働は可能) }\end{array}$ & $\begin{array}{c}\text { 厳しい } \\
\text { (労働不可能) }\end{array}$ \\
\hline 可動域制限 & なし & 正常の $75 \%$ & 内転位変形なし & 内転位変形あり \\
\hline 跛 行 & なし & 軽度 & 中等度 & 再脱臼例 \\
\hline 単純X線像 & 進行性変化 & 軽度 & 中等度 & 進行性変化あり \\
\hline
\end{tabular}

2 例は, 来院後直ちに整復操作を実施したが, 整復操 作中頸部骨折に転位が生じ，整復不能であった。この ため直達牽引とし, 後日人工骨頭置換術を行った.

整復後の治療法をタイプ別に見ると, $\mathrm{T}$ 一分類 type I の全例と, P - 分類 type I の 5 例中 3 例は保 存的に治療した. $\mathrm{T}$-分類 type II， III の 6 例と $\mathrm{P}-$ 分類 type I の 2 例は, 骨接合術または骨片摘出術を 行った. $\mathrm{P}$-分類 typeIIIの 2 例は人工骨頭置換術を 行った（表 1 ).

治療成績は, 最終診察時の, 股関節痛, 可動域制限, 跛行の程度と単純 X線像から, Thompson \&
Epstein の臨床成績判定基準 ${ }^{17)}$ を用い, excellent, good, fair, poor の 4 段階に判定した（表 2 ).

\section{結}

果

P - 分類 typeIIIの 2 例は, 人工骨頭置換術後のた め,この判定から除外した. 他の 15 例の治療成績は, excellent 3 例, good 11 例, fair 1 例之比較的良好な 結果であった. fair 1 例は股関節痛があり，軽度の可 動域制限と跛行が認められた。 しかし，他の症例では 股関節痛はなく, 可動域制限, 跛行とも軽度認められ たのみであった，X線像上大腿骨頭壊死，関節症変化 
を認めた症例はなかった。

治療成績をタイプ別に比較したが，とくに一定の傾 向は認めなかった（表 3 ）.

\section{症 例 供 覧}

症例 $8: 59$ 歳男性.

交通事故で受傷, T-分類 typeIIIである. 受傷後

表 3 type 別治療成績

\begin{tabular}{c|cccc}
\hline \hline 分類 & excellent & good & fair & poor \\
\hline $\mathrm{T}-\mathrm{I}$ & 1 & 2 & & \\
$\mathrm{~T}-\mathrm{II}$ & & 4 & & \\
$\mathrm{~T}-\mathrm{II}$ & 1 & 1 & & \\
$\mathrm{P}-\mathrm{I}$ & 1 & 3 & 1 & \\
$\mathrm{P}-\mathrm{II}$ & & 1 & & \\
\hline & 3 & 11 & 1 & \\
\hline
\end{tabular}

表中の数字は症例数

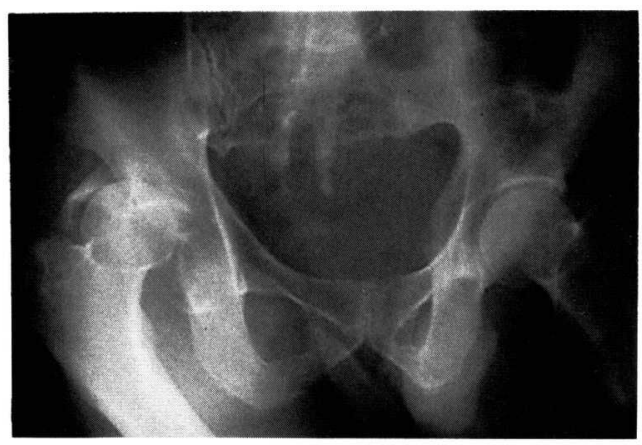

受傷時

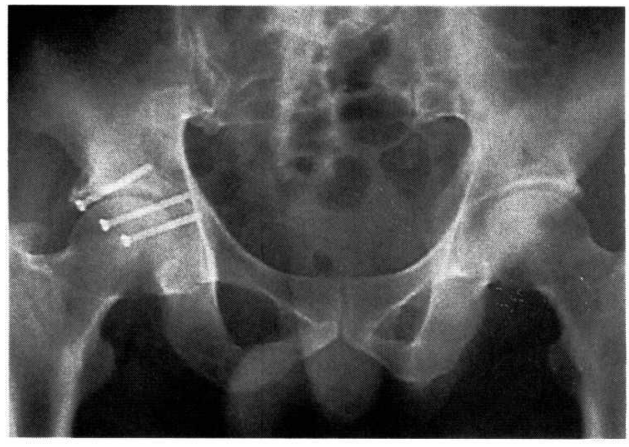

骨接合術後
7 時間で整復を行ったが，骨片が大きく，寛骨臼荷重 部であったため，8 日後にキャニュレーテッドキャン セラススクリューによる骨接合術を行った．固定不可 能であった小骨片は除去した。 2 年 9 力月後, X線像 上骨癒合良好で大腿骨頭壊死, 関節症変化屯認めない. 成績判定は excellent である（図 1 ）。

症例 $14: 29$ 歳女性.

交通事故で受傷，P－分類 type I である。受傷から 5 時間後に脱臼整復したが，骨片が大きくかつ遊離し ていたため 8 日後にハーバートスクリューによる骨接 合術を行った。現在 2 年 5 力月を経過し，X線像は良 好であり, MRI でも大腿骨頭壊死等の所見を認めな いが, 歩行時関節痛, 軽度の可動域制限, 跛行を認め, 臨床成績判定は fair である（図 2 ).

症例 $16: 45$ 歳女性.

交通事故で受傷，P - 分類 type III である．受傷時 の単純 X線像では頸部の骨折線は明らかではなかった。

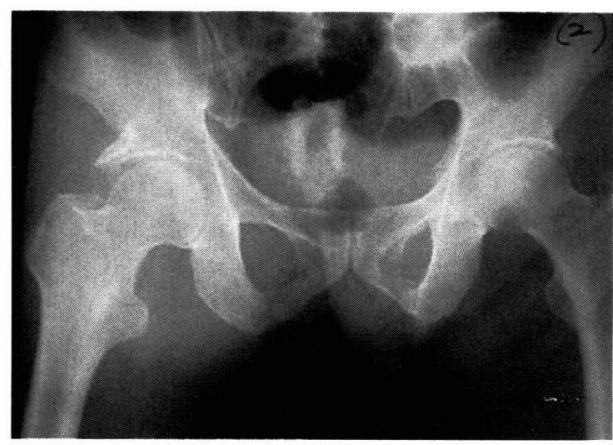

整腹後

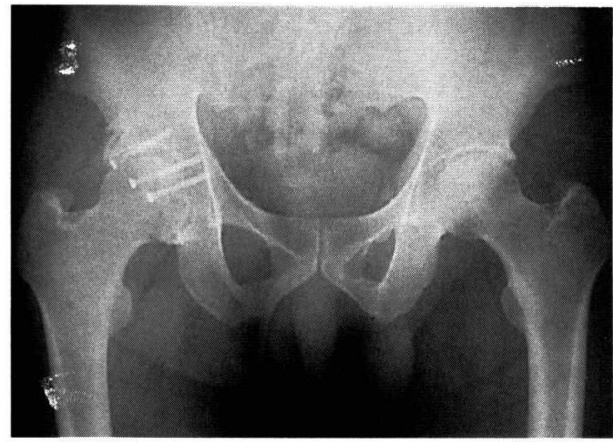

2 年 9 ケ月後

図 1 症例 8 のX線所見

59 歳，男性. T - 分類 type III. 寛骨臼に対し骨接合術実施，術後成績は excellent である。 


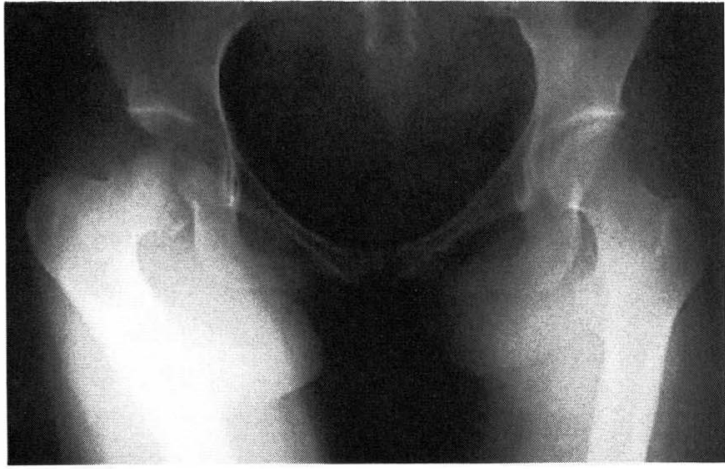

受傷時

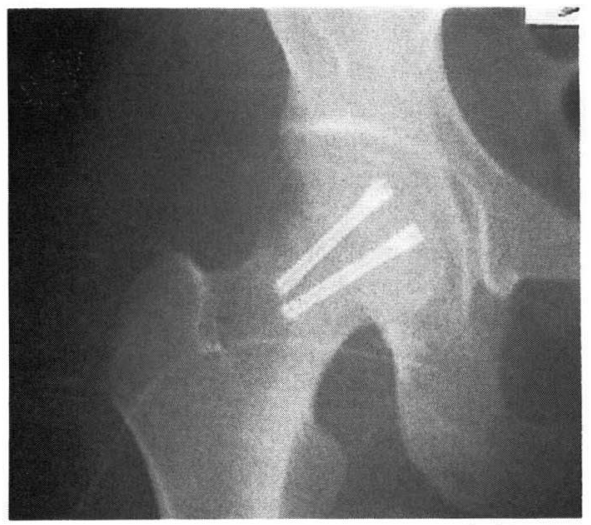

骨接合術後

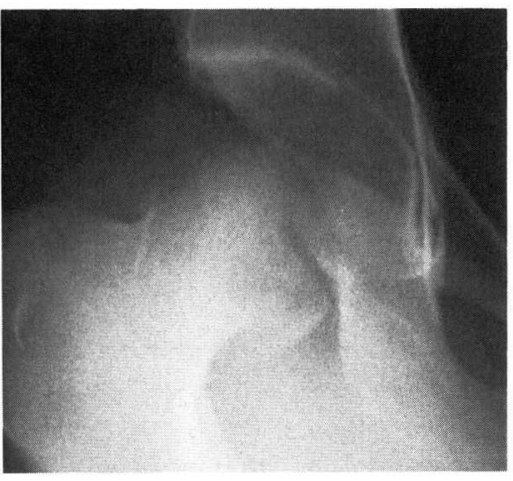

受傷時の拡大

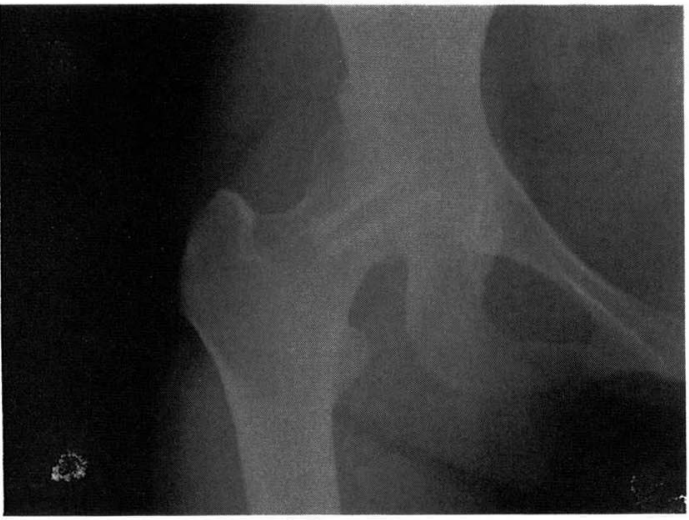

2 年 5 ケ月後

\section{図 2 症例 14 の X線所見}

29 歳, 女性. P - 分類 type I . 骨頭骨片をハーバートスクリューで固定した。術後X線像は良好で, MRI 上も所見は ないが，歩行時股関節痛があり，成績は fair である.

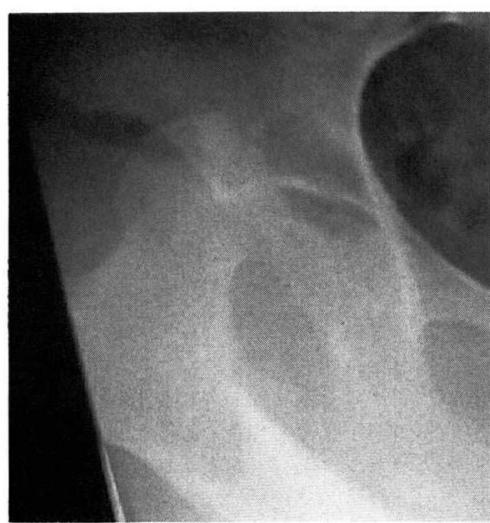

受傷時

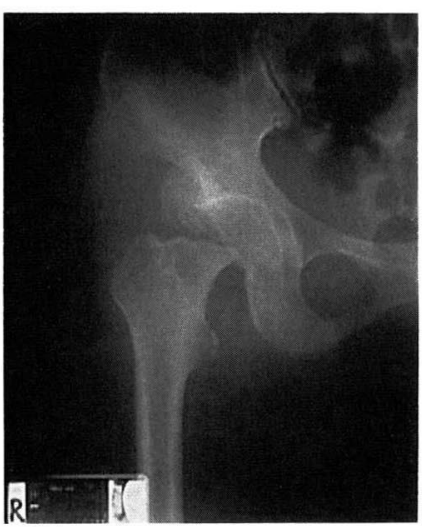

整腹後

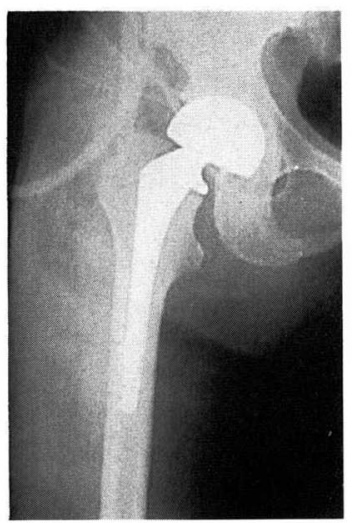

人工骨頭置換術後

図 3 症例 16 の 線所見

45 歳, 女性. P-分類 type III. 人工骨頭置換術を行った症例である. 
しかし, 整復操作により頸部骨折の転位が生じて整復 不能となり，10 日後人工頭置換術を行った，不用意 な整復操作が原因と考えられる症例である（図 3 ）。

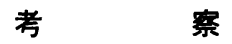

今回の調査では成績判定を行った 15 例の成績は， excellent 3 例，good 11 例，fair 1 例と比較的良好な 結果であった。これは大腿骨頭壊死と，变形性股関節 症の発生をみなかったことが大きな要因と考える，大 腿骨頭壊死の発生には，脱臼から整復までに要した時 間と，脱臼骨折の type の関与が大きい。このうち脱 臼から整復までの時間について，臨床的には $12 〜 48$ 時間を超えた症例で大腿骨頭壊死の発生頻度が高いと

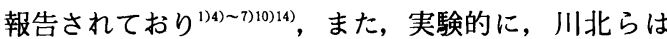
受傷後 9 時間を超えて整復されなければ血行障害は不 可逆性となると報告している ${ }^{13)}$. 我々の症例では整復 できた症例は全例 7 時間以内に整復されており, 大腿 骨頭壊死の発生をみなかった一因であったと考えた。 しかしながら我々は整復操作によって䅡部骨折に転位 が生じ，整復できなかった 2 例を経験しており，整復 を急ぐあまり不用意な操作とならないよう注意すべき であると考えた。

本外傷後の变形性股関節症の原因として, 骨折部の 整復不良，骨欠損による関節不安定性の発生，関節内 骨片の残存などが考えられる，骨折が寛骨臼，骨頭の 荷重部に及ぶ症例や，単純 X線または CT で関節内に 遊離した骨片のある症例については，解剖学的な整復， 内固定を行い，固定不可能な小骨片は摘出すべきであ ることは論を待たない。しかし P - 分類 type I の様 に，骨片が非荷重部のみであり，転位のみられない症 例については保存的治療 ${ }^{11)}$ ，骨接合 ${ }^{(5)}$ 。骨片摘出 ${ }^{2)}$ な よ゙，意見の一致をみていない，また，単純 $\mathrm{X}$ 線や $\mathrm{CT}$ でも検出できない微少骨片もあるという報告 ${ }^{12)}$ や，関 節内微少骨片が, chondrolytic enzyme 活性を上昇 させ変形性関節症を誘発するという報告 ${ }^{3)}$ から，全例 観血的治療の適応があるとする意見 ${ }^{8)}$ あある．我々は $\mathrm{T}$ 一分類 type I の 3 例と P - 分類 type I の 3 例に ついて保存的に治療したが，変形性股関節症は生じて いない。しかしながら経過観察期間が平均 2 年 6 力月 と短いことから，さらに長期間の経過観察を行っての 検討が必要であろう。

\section{ま と め}

1）外傷性股関節後方脱臼の治療成績を知る目的で 自験例 17 例の調査を行った.

2 ）人工骨頭置換術を行った 2 例を除く 15 例の治 療成績は, 経過観察期間平均 2 年 8 力月で excellent 3 例，good 11 例，fair 1 例之良好であり，大腿骨頭壊 死，変形性関節症を生じた症例はなかった。

3 ）脱臼整復は可及的速やかに行うべきであるが, 慎重な操作が必要である.

\section{参考 文献}

1) Brav, E. A. : Traumatic dislocation of the hip. J. Bone Joint Surg., 44-A : 1115-1134, 1962.

2) Epstein, H. C. : Posterior fracture-dislocation of the hip, long term follow up. J. Bone Joint Surg., 56-A : 1103-1127, 1974

3) Evans, C. H. : Experimental arthritis induced by intraarticular injection of allogenic cartilarginous particles into rabbit knees. Arthritis., $27: 200-208,1984$.

4）藤井敏之ら：外傷性股関節脱臼に合併した大腿骨頭骨 折の治療経験. 骨折 14:247-251，1992.

5）原田育生，新名正由，下村 裕：外傷性股関節脱臼の 問題点, 別冊整形外科 $10: 202-207,1986$.

6）本間政文ら：外傷性股関節脱臼の治療成績. 整形外科 $39: 1311-1318,1988$.

7）本間隆之ら：外傷性股関節脱臼の治療経験．別冊整形 外科 $23: 136-143,1993$.

8）池田 浩ら：外傷性股関節脱臼に合併した大腿骨頭骨 折 13 例 14 関節の治療経験. 整・災外 $31: 1519-1524$, 1988.

9）石田文夫ら：外傷性股関節脱臼・脱臼骨折の検討，骨 折 $10: 206-210,1988$.

10）伊藤 靖ら：骨頭骨折を合併した外傷性股関節脱臼の 治療経験。中部整災誌 $29: 1594-1596,1986$.

11）神 與市ら：股関節脱臼骨折の治療経験. 骨折 17 : 25-30, 1995.

12）片山 元ら：関節内骨片を伴う股関節脱臼骨折の治療 経験。整・災外 $30: 1057-1065,1987$.

13）川北 哲ら：外傷性股関節脱臼における脱臼持続時間 と骨頭血流の関係。中部整災 誌 $34: 719-721,1990$.

14）本川 哲号：骨折を伴う外傷性股関節後方脱臼の予後 骨折. $12: 116-119,1990$.

15）大野憲一ら：骨頭骨折を伴う外傷性股関節脱臼の治療 経験. 臨整外 $23: 1007-1012,1988$.

16）泉水邦洋ら：当院における外傷性股関節脱臼の治療経 験. 別冊整形外科 $23: 144-147,1993$.

17） Thompson, V. P., Epstein, H. C. : Traumatic dislocation of the hip. J. Bone Joint Surg., 33- A : 746-778, 1951. 